\section{Ode to an eddy}

The mighty stream Agulhas Wends its wand'ring way

Down the coast of Afrik And on past Durban Bay ${ }^{1}$.

Twas there we found The Eddy ${ }^{2}$,

Majestic and serene,

Cyclonically rotating:

The best we've ever seen.

Its heart was cool yet shallowIts motion slow and steady-

Its structure well-defined-

$\mathrm{Ah}$, yes, that was an eddy!

We know not of its birthplace,

Nor when it first saw day,

But Gründlingh has a theory:

They're born off Richards Bay ${ }^{3}$.

The coastline at St Lucia

Deflects the Mighty Flow,

And southwards in its wake

The eddies form and grow.

Yet that's not all the answer,

For other data shows

The inshore flow is governed

By the weather-bringing "lows"4,5.

These cells of falling pressure

Arrive from west-sou-west

And bring the dreaded "busters"'

Which the mariners detest.

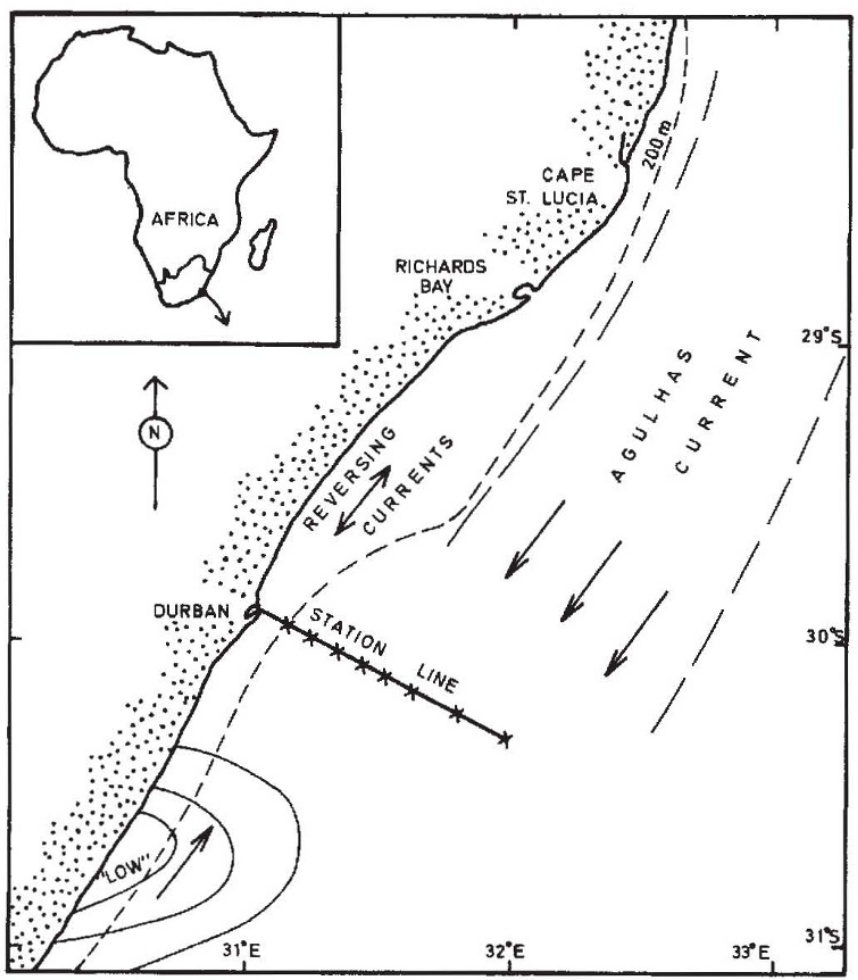

Fig. 1 Location chart, illustrating diagrammatically the general flow of the Agulhas Current, the reversing current on the continental shelf, the migration of a typical cyclonic cell from the south and the line of eight oceanographic stations. This line was occupied daily for the $5 \mathrm{~d}$ period February 19-23, 1973.

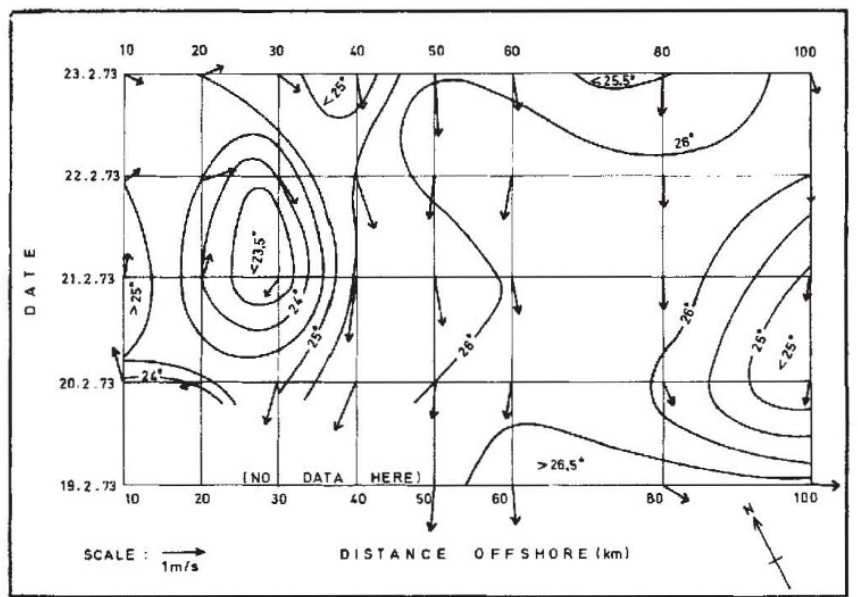

Fig. 2 The eddy is shown by the sea-surface temperature contours $\left(\frac{1}{2}{ }^{\circ} \mathrm{C}\right.$ intervals) and the current vectors measured at $10 \mathrm{~m}$ depth during the $5 \mathrm{~d}$ of the cruise.

And years of observation

Along the eastern coast

Suggest that eddies form

When pressure's down the most.

It therefore seems quite likely

That instead of from the north

It's really from the south

That the eddies issue forth.

Alas, our single section

(Repeated occupation)

Did not show the direction

Of eddy propagation.

Is it to north or south

The eddies set their face?

Or maybe they are born

and die in the same place ${ }^{7}$ ?

We're planning now a programme

To show them in their glory.

We'll seek them-find them-track themUntil we know their story ${ }^{8}$.

A. F. Pearce

National Research Institute for Oceanology,

Council for Scientific and Industrial Research,

PO Box 17001, Congella 4013, South Africa

${ }^{1}$ See the location chart in Fig. 1.

${ }^{2}$ Fig. 2. A more detailed publication on this and other eddies associated with the Agulhas Current is in preparation (at present they are described in various unpublished reports).

${ }^{3}$ Gründlingh, M. L., Deep-Sea Res., 21, 47-55 (1974).

${ }^{4}$ Anderson, F. P., Sharp, S. O., and Oliff, W. D., Symp. Oceanography in South Africa, Durban, 1970, paper H2, page 22.

${ }^{5}$ Pearce, A. F., South African National Oceanographic Symp., Cape Town, 1973, page 28 .

'The "lows" move up the coast from the south at intervals of a few days, and bring in their wake south-westerly winds; when these are of gale intensity, they are termed "busters".

${ }^{7}$ It is of course possible that standing eddies may be generated by the sudden change in the $200 \mathrm{~m}$ isobath north of Durban - there is evidence of semi-permanent patches of cooler water off Durban, shown by airborne radiation thermometer surveys.

${ }^{8}$ Eddies of a similar (?) nature associated with the Gulf Stream system have been described by Lee, T. N., dissertation, Florida State Univ. (1972). 